\title{
W.C. Coetzer
}

\section{GODSDIENS: MIDDEL TOT VERSLAWING OF TOT HELING?}

\author{
ABSTRACT
}

\section{RELIGION: A MEANS TO ADDICTION OR TO HEALING?}

There are two sides to religion, on the one hand the threat that implies emotional pain and addiction, on the other hand the healing and liberating effect of a balanced and healthy religion. In this article the focus is on the former. Factors which render people vulnerable to spiritual addiction are put on the table. Similarities between a dysfunctional family system and a dysfunctional church system as well as parallels between alcoholic families and dysfunctional Christian families play a significant role in this respect. Linking up with this we have a great measure of similarity between chemical addiction and religious addiction. Further attention is given to the progressive character of the process of addiction, the process of breaking free from the sick system as well as the various areas demanding attention during the process of healing. Concerning the latter particular attention is given to behaviour which could lead to a relapse.

\section{INLEIDEND}

Father Leo Booth verwys in sy boek, When God becomes a drug (1998:51), na die geval van Charles wat in 'n disfunksionele nie-godsdienstige huis opgegroei het. Sy jeugjare was gekenmerk deur gesinsgeweld, drankmisbruik en fisiese mishandeling. Hy het talle herinneringe gehad aan vrees, angs, pyn, verwerping asook selfmoord gedagtes en het deurgaans die droom gehad om van hierdie situasie te ontsnap. Op 15-jarige ouderdom het ' $n$ vriend hom saamgeneem na 'n sendingkerkie waar hy vir die eerste keer 'n boodskap van liefde en aanvaarding gehoor het - iets waaraan hy 'n intense behoefte gehad het. Dit lei uiteindelik tot ' $n$ totale geestelike oorgawe. Vanaf hierdie punt in sy lewe

Prof. W. C. Coetzer, Skool vir Kerkwetenskappe, Potchefstroomkampus, Noordwes-Universiteit, Potchefstroom, Bus 19320, Noordbrug 2522. E-pos: wentzel. coetzer@nwu.ac.za 
raak hy tot die ekstreme betrokke by die kerk en by godsdiens - tot so 'n mate dat dit tot vervreemding met sy familie lei en later ook die oorsaak word van sy egskeiding. Daar was konstante gevegte in die huwelik oor godsdiens omdat hy van mening was dat sy vrou op geestelike terrein slegs louwarm was, en sy van mening was dat hy rigied en fanaties was. Toe sy die dag finaal gegroet het, het sy vir hom gesê: "Religion is like a drug to you!" As gevolg van die pastorale begeleiding deur Father Booth kon Charles uiteindelik tot die besef kom dat sy vrou se evaluering van hom korrek was. Hy kon insig verkry in die feit dat in teenstelling met sy broers wat as gevolg van dieselfde disfunksionele gesin van oorsprong uiteindelik aan dwelms verslaaf geraak het ten einde van hul emosionele pyn te ontvlug, hyself ontvlugting gesoek het by wyse van 'n obsessiewe beheptheid met godsdiens. "Religion was his fix."

In sy boek, When religion gets sick (1970:16), verwys Wayne Oates na die feit dat godsdiens by geleentheid siek kan raak. Dit gebeur volgens hom wanneer godsdiens 'n aparte bestaan verkry, algeheel los van die totale uitdrukking van die betrokke persoon se lewe, en dit dan ontwikkel tot 'n eksterne "dit". Hierdie "dit" godsdiens word dan óf 'n gesegregeerde, outonome sisteem binne 'n lugdigte kompartement geskei van die res van die persoon se lewe, óf dit ontwikkel tot 'n steurende faktor binne die totale funksionering van hierdie persoon. In beide gevalle het die funksionering siek geraak. In die lig hiervan maak Oates dan ook die stelling dat die term godsdiens nie noodwendig dui op iets wat goed is nie. In sy bespreking van hierdie selfde tema kom die psigiater Scott Peck (2003:222) tot die gevolgtrekking dat dit juis om hierdie rede is dat talle psigiaters en psigoterapeute die standpunt huldig dat godsdiens die groot vyand is. In navolging van Freud kan hulle selfs godsdiens beskou as 'n neurose, "... a collection of inherently irrational ideas that serve to enchain people's minds and oppress their instincts toward mental growth." Volgens Oats (1970:18) verhoed die onderskeid tussen 'n siek en 'n gesonde godsdiens enersyds juis dat daar in die intellektuele doodloopstraat geland word van Freud se veronderstelling dat godsdiens 'n universele neurose te alle tye en plekke is. Andersyds vermy dit ook die oppervlakkige optimisme dat godsdiens, juis omdat dit godsdienstig is, noodwendig altyd verband hou met dit wat goed en opbouend en gesond is.

Teen die agtergrond van bovermelde inleidende opmerkings word daar vervolgens in hierdie artikel gefokus op die oënskynlike paradoks van godsdiens wat enersyds binne sekere kontekste 'n helende en bevrydende rol kan vervul, veral wanneer dit op gebalanseerde en gesonde wyse beoefen word en waar die motief daaragter suiwer en opreg is. Andersyds word gefokus op die gevaarkant van godsdiens. Met 'gevaar' word in hierdie konteks dan bedoel dat daar dieperliggende onverwerkte emosionele pyn aanwesig mag wees wat uiteindelik as dryfveer kan dien tot ontvlugting in oordrewe godsdienstige aktiwiteite - die finale resultaat van so 'n proses kan dan godsdienstige 
verslawing impliseer. In hierdie verband word daar vervolgens gelet op verskillende aspekte en omstandighede wat persone kwesbaar laat vir latere geestelike verslawing, veral dan ook die milieu van die disfunksionele gesin. Daar word ook gelet op ooreenkomste tussen chemiese verslawing en godsdienstige verslawing, die fases van die verslawingsproses asook riglyne betreffende 'n moontlike herstelproses.

\section{TOKSIESE GODSDIENS EN GEESTELIKE VERSLAWING}

Dupont (2004:39) verwys na toksiese geloof as 'n destruktiewe en gevaarlike verhouding met 'n godsdiens waarin die godsdiens en nie die verhouding met God die persoon se lewe beheer nie.

Arterburn en Felton (2001:83) beskryf verslawing as die gevolg van 'n psigologiese en fisiologiese afhanklikheid van 'n substans, verhouding of gedrag. Dit geld ook wanneer die persoon bereid is om gesin, werk, finansiële sekuriteit en geestesgesondheid op te offer ter wille van 'n substans, verhouding of gedrag. Hulle wys verder op die feit dat beoefening van geloof en betrokkenheid by godsdiens talle potensieel verslawende komponente bied. Persone kan gevolglik verslaaf raak aan gevoelens van regverdigheid, of die gevoel dat hy/sy uiteindelik reg is met betrekking tot 'n sekere saak. Daar kan 'n obsessie ontstaan met betrekking tot gebed. 'n Persoon kan verslaaf raak aan die emosionele hoogtepunte van lofprysing en aanbidding. Daar kan 'n verslawing ontstaan gekoppel aan die gevoel van deel te wees van iets groots. Aan die ander kant is dit so dat om deel te wees van 'n groep gelowiges oor die algemeen gevoelens van binding en samehorigheid genereer wat helend en opbouend kan wees. Die verslawing tree egter in wanneer hierdie emosies die doe/ van die oefening word eerder as die wonderlike byproduk van die aanbidding van God. Wanneer daar dus fokus verloor word en die gevoelens eerder as God die sentrale deel van die aanbiddings ervaring word, dan het die aanbidding toksies en verslawend geraak (Arterburn \& Felton 2001:98-99).

Booth (1998:50) vertel van die talle persone met wie hy berading gedoen het wat na hom gekom het met 'n verhaal van onvermoë om emosioneel te kon oorleef as gevolg van jare se emosionele en geestelike verwonding. In desperaatheid het hulle dan na godsdiens gegryp (gewoonlik 'n vorm van ongesonde en ongebalanseerde godsdiens) om dit te gebruik as 'n fix. Die enigste gevolg was dan uiteindelik 'n verslawing aan godsdiens met innerlik net meer pyn en wanhoop omdat daar op geen stadium aandag gegee is aan die diepere oorsake van die pyn nie. 


\subsection{Faktore wat mense kwesbaar maak vir geestelike verslawing}

Arterburn en Felton (2001:106) dui die volgende faktore aan as belangrik in hierdie verband (vergelyk ook Fischer 2007):

- 'n Ouer (veral die pa) wat misbruik toepas, hetsy fisies, emosioneel of seksueel.

- 'n Kind wie se emosionele behoeftes nie vervul is nie.

- Gevoelens van vervreemding - reeds gedurende die kinderjare.

- Houdings van perfeksionisme vanaf onvolmaakte ouers.

- Uitermate hoë verwagtinge van die kind.

- Die gebrek aan waardering en erkenning vanaf ouers.

- Ouers se probleme gekoppel aan verslawing.

- 'n Afwesige vader.

- Gevoelens van skuldig en vuil te wees.

- Swak verhoudinge met portuurgroepe.

- 'n Baie aktiewe fantasie wêreld wat dikwels ontvlugting bied.

- Die onvermoë asook onkunde betreffende die deel van innerlike gevoelens.

Dikwels word geestelike boodskappe gekommunikeer wat mense nie noodwendig nader aan God laat beweeg nie maar eerder bydra om die reeds bestaande vakuum in hul binneste net verder te vergroot. Hul desperate pogings om iets te vind om ten alle koste hierdie vakuum te vul, lei dan dikwels tot kompulsiewe en verslawende gedrag. Father Booth (1998:15) vertel in hierdie verband van die talle persone wat in berading aan hom gesê het dat hulle 'n liefde/haat verhouding met God ervaar. Wanneer hulle hoor van sy liefde dan is dit vir hulle wonderlik, maar dan staan dit telkens in kontras met die boodskappe wat hulle so dikwels tydens hulle jeugjare ontvang het. Een van hierdie persone het dit soos volg gestel:

The first words I remember as a child were 'God is going to get you.' And it went downhill from there. God was always to be feared. An angry God. A God who punished you and your family with sickness if you broke the rules. A God who was against laughter and fun. Father Leo, a part of me loves God. A bigger part of me hates God.

Ongesonde beskouinge omtrent hulself en God het uiteindelik hul lewens vergiftig en daartoe gelei dat hulle die godsdiens en ook God begin gebruik het ten einde van emosionele pyn te ontvlug (Blue 1993:106). 


\section{OOREENKOMSTE TUSSEN 'N DISFUNKSIONELE GESIN SISTEEM EN 'N DISFUNKSIONELE KERK- LIKE SISTEEM}

\subsection{Die pa se rol is deurslaggewend}

Carder (1995:131) toon aan hoedat mense geneig is om 'n kerk te soek wat gebaseer is op die styl van verhoudings waaraan hierdie persoon gewoond is. Die wyse waarop lede van die persoon se gesin van oorsprong in verhouding tot mekaar en in verhouding tot die outoriteit in die gesin gefunksioneer het, sal gevolglik bepalend wees met betrekking tot die tipe kerk wat hierdie persoon uiteindelik verkies. Persone wat byvoorbeeld opgegroei het in huise waar die pa ekstreem outoritêr was en nie verantwoording teenoor enigiemand verskuldig was nie, sal heelwaarskynlik aangetrokke wees tot 'n kerk waar die senior leraar op dieselfde wyse funksioneer. Dan is daar dikwels ook die onafgehandelde sake ("unfinished business") vanuit die gesin van oorsprong wat manifesteer binne die huidige kerklike opset (vgl. in hierdie verband ook Shaffer \& Hastings 2007:152). Die persoon wat die huis verlaat het vol van innerlike woede teenoor die pa gaan uiteindelik 'n kerklike opset vind wat ooreenstem met dié van die gesin van oorsprong en dan hul onderliggende woede rig op die leraar (as surrogaat vir sy/haar pa). Dieselfde rolle wat binne die gesin van oorsprong was, herhaal dan ook baie maklik weer binne die kerklike familie, met dieselfde spanning en pyn as binne die gesin van oorsprong. Hierdie frustrasie van telkens opnuut vasgevang te raak in die oorspronklike problematiek en spanning van die gesin van oorsprong lei dan ook daartoe dat sommige persone van kerk na kerk beweeg, altyd op soek na die perfekte kerklike familie-ervaring terwyl hul werklike innerlike pyn en frustrasies nooit hanteer word nie (Carder 1995:131; vgl. ook Brawand 1995:115).

\subsection{Parallelle tussen alkoholiese huise enersyds en dis- funksionele Christen huise andersyds}

Sloat (1990:14) wys op die groot ooreenkomste in die latere volwasse gedrag van enersyds kinders vanuit alkoholiese huise (ACA: Adult Children of Alcoholics) en andersyds kinders vanuit disfunksionele Christelike huise (ACE: Adult Child of Evangelicals; met die term evangelical lê hy klem op 'n streng, outoritêre en rigiede Christelike agtergrond en die bedoeling is nie dat dit noodwendig van toepassing is op alle sogenaamde evangelical huise nie). In sy navorsing het Sloat gevind dat binne talle disfunksionele Christelike huise daar basies dieselfde emosionele atmosfeer heers as wat die geval is in alkoholiese huise. Die mees prominente kenmerk is die afwesigheid van emosionele veiligheid vir die 
gesinslede. Sloat (1990:14) vergelyk in hierdie verband die situasies van twee persone met mekaar. Enersyds is Gene wat opgegroei het binne 'n alkoholiese huis en nooit geweet het wat om te verwag wanneer sy pa gedrink het of wanneer dit weer vir hom nodig sou wees om 'n geveg op te breek tussen sy ouers nie. Hierdie atmosfeer het diep innerlike onsekerheid by Gene gevestig en hom uiteindelik gelaat as 'n alleen en onsekere mens wat die belewenis gehad het dat niemand lief is vir hom nie. Hierteenoor is Cathy wat as kind net so kwesbaar was binne die Christelike huis waar sy opgegroei het, alhoewel drank geen rol gespeel het nie. Haar moeder was op 'n konstante basis nie daar vir haar wanneer sy beskerming en ondersteuning nodig gehad het nie en sy het ook geen persoonlike aandag aan Cathy gegee nie. Haar pa was totaal onbetrokke by haar en daar was ook nooit enige fisiese aanraking nie. Van niemand in haar huis het sy persoonlike ondersteuning ontvang betreffende haar innerlike worsteling met 'n klomp emosies nie. Die feit dat haar ouers aktiewe lede binne 'n lokale konserwatiewe kerk was en ook ernstige Christene, het geen invloed gehad op die wyse waarop hulle haar hanteer het nie. Sloat (1990:15) kom tot die gevolgtrekking dat kinders wat opgegroei het binne 'n alkoholiese huis of binne 'n disfunksionele Christelike huis heel dikwels nie heel persone is nie, "... although the ones from the Christian homes may see themselves as "holy."

\section{3 'n Ongesonde beroep op die outoriteit van God en sy Woord}

Afgesien van laasgenoemde aspek is daar ' $n$ verdere belangrike verskil tussen hierdie twee tipes huise. Dit hou verband met die feit dat Christen ouers wat 'n kompulsiewe behoefte het om hul kinders te beheer, 'n bron tot hul beskikking het wat nie die geval is in die alkoholiese huise nie. Hulle beroep naamlik hulself dikwels op God en op die Woord in hul persoonlike pogings om beheer uit te oefen. Uitsprake soos die volgende sou dan algemeen kon voorkom: "Wat sou Jesus sê as Hy sien dat jy dit doen?" Dit is baie duidelik bedoel om skuld en skaamte by die kind te wek ten einde te voldoen aan die ouers se wense. Dit kan egter 'n platform skep vir heelwat probleme later. Een uitvloeisel sou kon wees 'n Christelike weergawe van 'n disfunksionele huis wat dan negatiewe oorlewingspatrone by die kinders vestig asook die vestiging van 'n basis om uiteindelik ACE's te wees - persone wat opgegroei het in Christelike huise waar die werklike betekenis van Christendom, God en die lewe self verdraai is. Die volwasse lewe vir sulke ACE's impliseer dikwels emosionele en geestelike konflik, depressie, angs, selfmoord gedagtes asook 'n onsekerheid betreffende die werklike oorsprong van hierdie ongemak in hul binneste. Wanneer sulke volwassenes dan later ook self ouers is, is die risiko baie groot dat hulle dieselfde vrees-gebaseerde benadering sal volg waar Christelike reëls op 'n rigiede wyse toegepas word op persoonlike ontwikkeling (Sloat 1990:16). 


\subsection{Die reëls binne 'n disfunksionele huis}

Literatuur oor ACA (Benton 2007; Bradshaw 2000:8; Pierce 2007) identifiseer veral die volgende drie tipiese reëls wat kinders moet bemeester ten einde in so 'n atmosfeer te kan oorleef: moenie praat nie, moenie vertrou nie, en moenie voel nie. Wanneer sulke kinders uiteindelik die fase van volwassenheid betree dan mag hulle suksesvol voorkom. Innerlik is hulle egter ongelukkig, ontevrede en dikwels leeg aangesien hul oorlewing strategieë tydens die kinderjare 'n swak voorbereiding was vir die volwasse jare - veral wanneer hulle poog om intieme verhoudinge met andere te vestig. Die bovermelde reëls wat hulle moes leer kan enige poging tot nabyheid en intimiteit dwarsboom en daarom sal hierdie reëls eers uitgekanselleer moet word. Sloat (1990:18) beskryf dat hy gevind het dat daar ook 'n 'Christelike' weergawe is van die ACA reëls wat funksioneer binne disfunksionele Christelike huise, alhoewel drank hier geen rol speel nie. Talle volwasse kinders uit sulke huise ervaar ook probleme om te kan praat, te kan vertrou en te kan voel aangesien hulle net soos Cathy (wat in die Christelike huis opgegroei het) nie veilig genoeg voel om standpunt in te neem of om enigiemand te vertrou nie. Waar daar geheime alkoholisme binne so 'n disfunksionele Christen huis sou voorkom, kry sulke kinders 'n dubbele dosis: al die vernietigende gevolge van 'n alkoholiese huis plus ook nog die gevolge van 'n disfunksionele Christen huis. Dit alles skep die ideale milieu vir uiteindelike geestelike verslawing.

Betreffende die kwessie van verslawing sê Booth dat hy in talle Christen huise dieselfde houdings en gedragspatrone aangetref het wat lank reeds geïdentifiseer is as dié van alkoholiste, verslaafdes en mede-afhanklikes.

I saw a family of God as dysfunctional as any family of an alcoholic I have ever met... The more I examined the idea of the dysfunctional family of God, the clearer it became. In the excessive tithing and giving I saw the same compulsive urgency l've seen in gamblers. In the dedication to church ritual I saw the sex addict's need for ritualizing. In the glazed, hypnotized look of a woman quoting scripture at me, I saw the drugged stare of addicts after a fix (Booth 1998:18).

\section{OOREENKOMSTE TUSSEN CHEMIESE VERSLAWING EN GODSDIENSTIGE VERSLAWING}

In hul bespreking van die ooreenkomste tussen chemiese verslawing en godsdienstige verslawing wys Johnson en VanVonderen (1991:189) op die feit dat dit by chemiese verslawing onder andere gaan om die afhanklikheid van 'n gemoedsveranderende substans. In die proses word tyd, energie, eerlikheid en geld geïnvesteer in die verslawing en verhoudings ly skade. Mettertyd word 
al meer investering vereis ten einde te vergoed vir vorige verliese. Ontkenning gaan uiteindelik oor in misleiding en delusie en die verslaafde verloor perspektief betreffende die skade wat die substans aanrig asook betreffende die negatiewe impak op andere se lewens. Op soortgelyke wyse kan daar 'gemoeds-verandering' plaasvind binne geestelik afknouende sisteme. Dit gebeur wanneer die betrokke persoon sy/haar ongesonde tegnieke rondom verhoudings in diens van God probeer aanwend, eerder as wat hulle die pynlike roete volg van hulp te aanvaar wat op ware verandering en heling kan uitloop. Om deur sulke pogings die goedkeuring van mense en van God na te streef kan 'gemoedsveranderend' wees. Daar word verwys na hierdie toestand van afhanklik te wees van 'n geestelike gemoedsveranderende sisteem as 'godsdienstige verslawing'. Op hierdie stadium moet hierdie persoon meer en meer van sy/haar lewe investeer in 'n sisteem vol van beloftes maar met 'n onvermoë om dit te laat realiseer. Jy ontken wat jy sien, hoe jy voel, hoe moeg jy is, hoeveel probleme jy het, en jy noem dit alles geestelik. Jou vriende probeer om jou te waarsku maar jy kan hulle nie hoor nie en jy is uiteindelik vasgevang in die slagyster van 'n geestelik aftakelende sisteem (Johnson \& Van Vonderen 1991:190).

\section{DIE FASES ASOOK PROGRESSIEWE KARAKTER VAN DIE VERSLAWINGSPROSES}

Booth (1998:37) vertel van 'n brief wat hy ontvang het waarin iemand vertel van die pynlike wyse waarop sy bewus geraak het van haar verslawing aan godsdiens asook die effek daarvan op haar lewe. Sy verwys na haar kompulsiewe aanhaling van Skrifgedeeltes en haar obsessie oor haar eie godsdienstige oortuigings, wat weer dikwels aanleiding gegee het tot argumente met familie en kollegas. Sy beskryf die uiteindelike isolasie van die mense vir wie sy lief was asook haar groot finansiële probleme as gevolg van die groot bedrae geld wat sy aan die kerk geskenk het. Namate emosies soos alleenheid, woede, depressie, vrees en skuldgevoelens toegeneem het, het sy haar betrokkenheid by godsdienstige aktiwiteite verhoog. Hoe meer obsessief sy egter oor godsdiens geraak het hoe meer hulpeloos en geïsoleer het sy gevoel. Sy het dikwels probeer om haar kompulsiewe gedrag te stop deur minder kerk toe te gaan, beeldjies en kruise en wierook branders uit haar huis te verwyder, nie soveel ure voor godsdienstige TV-kanale deur te bring nie, haar soms te onttrek vanaf ander gemeentelede, telefoon oproepe van haar leraar nie te beantwoord nie, en intekening op verskeie godsdienstige tydskrifte te termineer. Telkens het sy egter net terug geval in meer intense godsdienstige verslawing met nog meer gevoelens van skuld en skaamte. Uiteindelik het sy vir berading gegaan en het sy 'n tipe van 'godsdiens-ontgifting' (religious detox) ondergaan. Daarna kon sy voortgaan met 'n meer gesonde en gebalanseerde spiritualiteit. 
What she described was the classic progression of an addiction. We could substitute alcohol, cocaine, or food, and the pattern would be the same (Booth 1998:38).

Die progressie van godsdienstige verslawing sou aan die hand van die volgende drie fases beskryf kan word (Booth 1998:45; Arterburn \& Felton 2001:107; Johnson \& VanVonderen 1991:190; Mazhar 2009; Baute 2009):

\subsection{Vroeë stadium}

- Herhaaldelike teleurstellings - begin al meer soek na kitsoplossings.

- Ekstreme stres wat geestelike onderskeidingsvermoë negatief beïnvloed.

- Kry nêrens antwoorde nie.

- Gevoelens van waardeloosheid.

- Begin om geestelike antwoorde te soek as 'n laaste opsie.

- Alleenheid - aandag en redding van watter kant af ook al sal verwelkom word.

- Al meer twyfel en vrae oor God - geestelik kwesbaar.

- Al meer skuldgevoelens asook 'n gebrek aan innerlike sekuriteit.

- Eerste ervaring met toksiese geloof sisteem bring gemoedsverandering.

- Elke verdere ontmoeting lei tot groeiende aangetrokkenheid.

- Al groter konformiteit met ander verslaafdes.

- Die Bybel word gebruik om sekere senutoestande onder beheer te bring.

- Kerkbywoning en Bybelstudie tot die ekstreme.

- Die kombinasie kerk/Bybel/gebed word op kompulsiewe wyse gebruik ten einde dieperliggende probleme te vermy.

- Swart/wit denke neem toe.

- Kom al meer laat by die werk en ook al meer afwesig by familie/gesins geleenthede as gevolg van godsdienstige byeenkomste.

- Die praktyk van toksiese geloof vervang al meer vriende en familie en ook ander belangstellings.

- Eenkant gestoot deur vriende en familie - hulle raak al meer geïrriteerd.

- Groeiende ontkenning en selfregverdiging. 
- 'n Onwilligheid om probleme te bespreek wat verband hou met toenemende onbeheerbare gedrag.

- Geneigdheid om voortdurend vir andere te 'preek'.

- Geloof word gefokus op 'n spesifieke kerklike leier.

- Die Skrif word 'n wapen - verse word aangehaal om andere mee te veroordeel en eie optredes mee te regverdig.

\subsection{Middel stadium (fase van verlies van beheer)}

- Toenemende rasionalisering.

- Totaal ingetrek in die sisteem.

- Toenemende gebruikmaking van kerk/Bybel/gebed ten einde probleme te vermy.

- Obsessiewe en oormatige betrokkenheid by gebedsessies en uitreike.

- Obsessief oor proselietemakery waardeur mense deel van die sisteem kan word en nie noodwendig nader aan God beweeg nie.

- Rigiede en obsessiewe nakoming van reëls, kodes en etiese riglyne.

- Al meer verlies aan ander belangstellings.

- Obsessie oor kerk/godsdiens/leraar.

- Toenemende afhanklikheid van godsdiens.

- Skuldgevoelens wanneer kerklike funksies nie bygewoon kan word nie.

- Seksualiteit word as vuil beskou.

- Tye van gebed en vas tot die ekstreme - by sommige ontwikkel 'n eetversteuring.

- Self-medikasie. Elke nuwe dag moet daar gesoek word na 'n nuwe godsdienstige 'high'. "The religious experience becomes an intoxicating high that medicates the addict's high" (Arterburn \& Felton 2001:123).

- Teleurstelling indien die emosionele katarsis nie plaasgevind het nie en 'n soeke om dit dan op ander wyses te laat realiseer.

- Dubbele verslawings. Ander verslawings kan ontwikkel, gekoppel aan byvoorbeeld kos, drank of seks.

- 'n Weiering om enigsins krities te dink betreffende kerklike informasie of outoriteit — baie uitgesproke. 
- Die onvermoë om op 'n sinvolle wyse godsdienstige aangeleenthede te bespreek.

- Hanteer verwerping moeilik - skryf diegene totaal af wat nie ontvanklik is vir indoktrinasie nie.

- Self gefabriseerde sowel as outentieke gawes word gebruik om andere uit te buit en te manipuleer.

- Aansprake op spesiale gawes en salwing.

- Al meer isolasie vanaf andere.

- Nie-godsdienstige vriende en familie word veroordeel of vermy, of daar word gepoog om hulle ten alle koste te oortuig.

- Hoogdrawende of aggressiewe gedrag.

- Konflik met skool of werk.

- Verloor betrekking omdat elke faset van die persoon se lewe geaffekteer geraak het deur die toksiese geloof.

- Geldelike probleme omdat buitensporige bedrae geskenk word ten koste van die gesin se basiese behoeftes.

- Die verslaafde het totaal afhanklik van die sisteem geraak om te oorleef.

- Verdiepende ontkenning - 'n totale onvermoë om te besef wat die prys is wat betaal word.

Die persoon het uiteindelik 'n punt bereik wat treffend deur Baute (2009) soos volg saamgevat word:

In essence we have become addicted to the certainty, sureness or sense of security that our faith provides. It is no longer a living by faith, with hope and growing in unconditional love.

\subsection{Laat stadium}

- Wanhoop en gevoelens van hopeloosheid omdat die sisteem nie die verwagte resultate lewer nie.

- Gryp na allerlei strooihalms vir oplossings - soek antwoorde in gedragsaanpassings maar nie in die diepgaande evaluering van eie onverwerkte emosionele pyn nie.

- Magiese denke wat impliseer dat God alle probleme uit die weg gaan ruim sonder enige insette deur die persoon self. 
- Ontvang 'boodskappe' van God.

- Woede en bitterheid namate eie wêreld inmekaar tuimel - al die ander word beskuldig.

- Radikale agteruitgang van verhoudings.

- Enersyds openlike uitsprake oor seks as vuil — andersyds seksuele kompulsiewe/obsessiewe gedrag (sexually acting out).

- Gevoelens van magteloosheid omdat aangeleerde geloof-reëls nie klop met die huidige praktyk nie.

- Diepe depressie - disintegrering van geloof sisteem lei tot die onvermoë om te kan funksioneer.

- Fisiese en psigiese agteruitgang — depressie en stres eis hul tol.

- Al meer psigosomatiese siektes en simptome soos rugpyne, slaaploosheid, hoofpyne, hipertensie, ens.

- Onvermoë om sinvolle besluite te neem.

- Stagnering - obsessief besig om foute van die verlede te bedink.

- Verslawing aan seks, kos, pille, ens., intensiveer namate die persoon soek na ontvlugting.

- Oormatige vrees - die persoon beleef ' $n$ intense gebrek aan sekuriteit sien elke persoon as 'n bedreiging en ervaar vrees om in die sisteem aan te bly sowel as om die sisteem te verlaat.

- Gaan soms in 'n trans

- Totale vereensaming, isolasie en finansiële ineenstorting.

- Fisiese, verstandelike en emosionele uitputting.

- Gesin en familie verhoudinge stort ineen as gevolg van stres en gebrek aan vertroue - dikwels buite-egtelike verhoudings en soms egskeiding.

- Sommige is op hierdie stadium bereid tot terapie en soms ook psigiatriese hulp.

- Hospitalisering.

\section{DIE PROSES VAN WEGBREEK}

Een van die hoof kenmerke van 'n verslawende sisteem is die feit dat dit baie moeilik gemaak word vir mense om uit te beweeg. Binne 'n gesonde 
sisteem daarenteen sal leiers nie struikelblokke in die weg plaas van diegene wat wil bedank nie. Die breuk met 'n verslawende sisteem sal dikwels ook deur mense beleef word as 'n rouproses waarvoor tyd nodig is. As deel van hierdie rouproses sal emosies soos woede, depressie en selfs wanhoop normaal wees en persone moet daarom aan hulself die nodige tyd gun en ook geduldig wees met hul emosies.

If you were hit by a bus, you would need time to recover. Something almost as serious as that has happened to you. Take time. Let yourself heal (Blue 1993:135).

Enroth (1993:92) wys op die intense worsteling rondom skuldgevoelens by diegene wat uiteindelik die punt bereik waar hulle 'n geestelik verslawende sisteem verlaat. Sulke kerke en groepe is voorgehou as 'n utopia en met 'n skok moet daar uitgevind word dat so 'n utopia nie bestaan nie (vgl. ook Pretorius 2007:215). VanVonderen (1989:79) wys op die gevaar dat persone wat so 'n sisteem verlaat uiteindelik nie werklik toegerus is vir die normale wêreld daar buite nie. Om verskillende redes kan hulle dan uiteindelik soos droë blare heen en weer gewaai word en baie maklik in ander aftakelende sisteme ingetrek word. Enroth (1993:20) beskryf die geweldige verwarring waardeur sulke persone gaan soos volg:

They will share the pain of leaving an abusive church and the struggle to adjust to life on the outside. For many of them, life in an all-encompassing Christian environment has been so devastating that they find it difficult sometimes to read their Bible, attend church, or even believe in God (vergelyk ook Dowhower 1995:259).

Johnson en VanVonderen (1991:191) dui die volgende vier voorwaardes aan wat nagekom moet word ten einde in staat te wees om uit die verslawende sisteem uit te beweeg:

- Slagoffers moet die punt bereik waar hulle besef dat hulle geestelik misbruik is en dan bereid wees om hulp te aanvaar.

- 'n Vernuwing van denke moet plaasvind aangesien hulle op 'n baie konkrete wyse as't ware geestelik gebreinspoel is.

- Daar moet veilige verhoudings wees waarbinne hulle kan genees van hul emosionele, psigologiese en geestelike wonde.

- Binne so 'n veilige milieu moet aan hulle die toestemming verleen word en ook die geleenthede gebied word om gaandeweg hul sin vir identiteit as 'n gawe van Jesus Christus te ontvang.

Trahan (1995:144) toon die volgende aan as tipiese probleme waarmee persone te doen kry na die wegbreek: 
- Verwarring. 'n Worsteling met die vraag of dit die regte besluit was om uit te beweeg, en/of dit nie eintlik maar dui op mislukking omdat die persoon basies nie in staat was om hom/haarself ten volle aan God te verbind nie - ook verwarring ten opsigte van wat presies om aan te voer as redes vir die losmaking proses.

- Die verlies van 'n ondersteuning stelsel. Omdat alle verhoudings buite die groep mettertyd op die agtergrond geskuif het, staan mense soms totaal alleen nadat hulle uitbeweeg het. "Almost all of our friends outside the group were gone, driven away by our ceaseless barrage of cult jargon."

- Woede. Dit kan woede oor eie gebrekkige insig wees asook woede teenoor die groep.

- Skuldgevoelens. Dit kan verband hou met optrede waardeur vriende en familie vervreem is; skuldgevoelens oor al die proseliete wat gemaak is en hulle families wat gevolglik pyn ervaar het. "I was ashamed of the kind of person I had become and of the things I had done."

- 'n Gebrek aan eiewaarde. Deur 'n proses sal nuwe selfvertroue asook vertroue in eie vermoëns ontwikkel moet word.

Giambaluo (1995:151) voeg ook nog die volgende aspekte by:

- Die gevoel van sinneloosheid en 'n totale gebrek aan kontak ("being disconnected").

- Die ervaring van 'n rouproses as gevolg van vriende van wie afskeid geneem moes word.

- 'n Totale gebrek aan vertroue in hul eie onderskeidingsvermoëns asook 'n gebrek aan vertroue in andere.

- Vrees dat dít sal gebeur wat die groep voorspel het indien hulle die groep sou verlaat.

- 'n Rigiede geneigdheid tot 'n swart/wit tipe denke.

- Die spiritualisering van alles en 'n magiese denkpatroon - hier moet hulle gehelp word om met die realiteit te deel.

- Die onvermoë om besluite te neem.

- Probleme met werkgewers en/of loopbane.

- Dissosiasie.

- Nagmerries en soms ook hallusinasies.

- Kwessies rondom seksualiteit. 
- Die onvermoë om te konsentreer en soms ook verlies van korttermyn geheue.

- Hernude worsteling met emosionele en psigologiese probleme wat aan die orde was voordat hulle by die sieklike sisteem betrokke geraak het.

- Ongeduld met die herstelproses.

\section{AREAS WAT AANDAG MOET KRY TYDENS DIE HERSTELPROSES}

Wat betref die herstelproses gee Booth (1998: 200) die volgende skema as 'n riglyn met betrekking tot die groot areas wat aandag moet kry:

\subsection{Identifiseer gedragspatrone waardeur die verslawing in die verlede gemanifesteer het}

Tipiese aspekte in hierdie verband waaraan gewerk sal moet word, is die volgende:

- Die weiering om selfstandig te dink, te betwyfel of vrae te vrae.

- Totale fokus op godsdienstige TV-programme met uitsluiting van enige ander kanaal.

- Die weiering om aan gesinslede godsdienstige keuses te bied.

- Disfunksionele seksuele praktyke en/of oortuiginge.

- Veroordeling van andere met teenoorstaande standpunte.

- Rigiede navolging van reëls.

- Buitensporige finansiële bydraes.

- Obsessiewe betrokkenheid by kerklike dienste, aksies en uitreike.

- Proselietmakery.

- Kompulsiewe aanhaling van Bybeltekste en kompulsiewe beoefening van uitgerekte fases van gebed.

- Mense word op platforms geplaas - outoriteit figure is altyd reg.

- Eetversteurings of ander verslawings.

- Die vermyding van sekulêre aktiwiteite - dit wat verband mag hou met plesier, kultuur, opvoeding, ens.

- 'n Rigiede swart/wit denkwyse. 


\subsection{Lê grense neer met betrekking tot gedrag}

Die hoofoogmerk is balans, en met betrekking tot die voormelde lys van moontlik verslawende gedrag kan daar nou besluit word of 'n sekere gedrag getermineer moet word en of dit in 'n sekere mate ingeperk moet word. Dit kan vergelyk word met kosverslawing waar daar aanvanklik besluit kan word om sekere kossoorte totaal uit te sny en slegs beperkte hoeveelhede van ander te geniet - dit alles om struktuur aan die nuwe gedragspatroon te gee. In hierdie proses van die neerlê van grense is daar gevolglik die volgende vier opsies:

- Weerhouding van die aktiwiteit in geheel.

- Elimineer dit vir'n sekere tydperk (Jack Frost (2006) vertel dat hy vir ongeveer agtien maande na die positiewe keerpunt in sy lewe dit baie moeilik gevind het om deel te neem aan enige georganiseerde godsdienstige aktiwiteite).

- Beperk deelname tot slegs sekere omstandighede.

- Vervang die verslawende gedrag met gesonde gedrag.

\subsection{Identifiseer snellers of gevaar areas wat aanleiding kan gee tot 'n terugval}

Voorbeelde in hierdie verband sou die volgende kon wees:

- Preokkupasie of rigiede navolging van reëls, etiese kodes of rituele.

- Isolasie binne 'n ondersteuningsgroep en geen assosiasie met 'n verskeidenheid van persone nie.

- Die verering van outoriteit figure en die onvermoë om hulle te bevraagteken.

- Die herhaalde terugval op aanhalings vanuit die vorige groep se leerstellings.

- Hiper krities en veroordelend teenoor diegene wat selfs binne die ondersteuningsgroep nie al die reëls stiptelik nakom nie.

- 'n Obsessie rondom gevoelens van onvermoë.

- 'n Voortsetting van die denkwyse dat hy/sy as persoon geen eie keuses het nie en dat God die rigting en die antwoorde sal voorsien.

\subsection{Definieer gedrag wat moontlik tot 'n terugval aanleiding kan gee}

In die lig van die voormelde lys van moontlike snellers of gevaar areas kan die persoon tesame met die berader en ondersteuningsgroep nou daardie 
aspekte identifiseer wat in 'n besondere mate op hom/haar van toepassing is.

\subsection{Gebruik bevestigende gedagtes of gedrag wat gesonde uitgangspunte reflekteer ten einde disfunk- sionele denke te vervang}

Voorbeelde hiervan sou die volgende kon wees:

- Ek is vergenoeg.

- God help my om gesonde keuses te maak.

- Ek is verheug oor my gesonde spiritualiteit.

- Ek ervaar God se kreatiwiteit in my lewe deur byvoorbeeld my eie persoonlike gebede te skryf, deur kleurprente te teken van my innerlike kind ("inner child") se gevoelens, of deur 'n instrument te leer speel.

- Ek verbreek my isolasie deur te sosialiseer na byeenkomste.

- Ek vier my keuse om 'n behoorlike begroting op te stel betreffende my tiendes.

- Ek versorg myself deur my dag te begin met ten minste 'n twintig minute stiltetyd.

\section{SAMEVATTING EN KONKLUSIE}

Vanuit die voormelde bespreking het duidelik geblyk die vernietigende en verslawende rol wat godsdiens kan speel indien daar ongesonde en disfunksionele onderliggende motiewe is. Vir die kerk in die breë bied hierdie terrein 'n geweldige uitdaging en indien die riglyne soos uitgespel hierbo, gevolg word, kan dit vir talle persone wat godsdienstig verslaaf en verwond geraak het, ' $n$ deur open tot ' $n$ fase van nuwe geestelike groei, genesing en vryheid. 


\section{BIBLIOGRAFIE}

Arterburn, S. \& Felton, J.

2001. Toxic faith. Experiencing healing from painful spiritual abuse. Colorado Springs, Colorado: Shaw Books.

BAute, P.

2009. Symptoms of religious addiction. [Aanlyn.] Bekom van: http://www.lexpages. comSGN/paschal/religious_addiction.html [2009, 10 Oktober].

Benton, S.A.

2007. Dysfunctional families: Recognizing and overcoming their effects. Brochure adapted from Kansas State University. [Aanlyn.] Bekom van: http://www.k-state.edu/ counseling/topics/relationships/dysfunc.html [2007, 28 Maart].

BLUE, K.

1993. Healing spiritual abuse. How to break free from bad church experiences. Downers Grove, Illinois: InterVarsity Press.

BоОтн, L.

1998. When God becomes a drug. Breaking the chains of religious addiction and abuse. Dalkeith, UK: SCP Publishers Ltd.

BRADSHaW, J.

2000. Home coming. Reclaiming and championing your inner child. London: Piatkus.

Brawand, A.

1995. Dysfunctional families in 'the ministry'. In: M.A. Carder, E. Henslin, J. Townsend, $\mathrm{H}$. Cloud \& A. Brawand (eds.), Secrets of your family tree. Healing for adult children of dysfunctional families (Chicago: Moody Press), pp.113-130.

CARDER, D.

1995. Local church 'family patterns'. In: M.A. Carder, E. Henslin, J. Townsend, H. Cloud \& A. Brawand (eds.), Secrets of your family tree. Healing for adult children of dysfunctional families (Chicago: Moody Press), pp.131-146.

DOWHOWER, R.L.

1995. Guidelines for clergy. In: M.D. Langone (ed.), Recovery from cults. Help for victims of psychological and spiritual abuse (New York: W.W. Norton \& Company), pp. 251-262.

Dupont, M.A.

2004. Toxic churches. Restoration from spiritual abuse. Grand Rapids, Michigan: Chosen Books.

ENROTH, R.M.

1993. Churches that abuse. Grand Rapids, Michigan: Zondervan Publishing House.

FISCHER, T.F.

2007. Ten commandments of dysfunctional families. [Aanlyn.] Bekom van: http:// ministryhealth.net/mh_articles/064_ten_commandments_of_dysfunctional_families.html [2007, 28 Maart]. 


\section{FROST, J.}

2006. Spiritual slavery to spiritual sonship. Shippensburg, PA: Destiny Image Publishers, Inc.

Giambaluo, C.

1995. An exit counselor's perspective. In: M.D. Langone (ed.), Recovery from cults. Help for victims of psychological and spiritual abuse (New York: W.W. Norton \& Company), pp. 148-154.

JOHNSON, D. \& VANVONDEREN, J.

1991. The subtle power of spiritual abuse. Cape Town: Struik Christian Books.

MAZHAR, U.

2009. Religious addiction: inner peace or inner turmoil? [Aanlyn.] Bekom van: http:// www.crescentlife.com/spirituality/religious_addiction.htm [2009, 10 Oktober].

OATES, W.E.

1970. When religion gets sick. Philadelphia: The Westminster Press.

PECK, S.

2003. The road less travelled. New York: Touchstone.

PIERCE, L.

2007. Dysfunctional families. What exactly does that mean? [Aanlyn.] Bekom van: http://www.selfhelpmagazine.com/articles/parenting/dysfam1.html [2007, 28 Maart].

Pretorius, S.P.

2007. Establishing mutual ground that enables counseling of religious cult victims. Tydskrif vir Christelike Wetenskap 43(4):201-216.

Shaffer, B.A. \& HAstings, B.M.

2007. Authoritarianism and religious identification: response to threats on religious beliefs. Mental Health, Religion \& Culture 10(2):151-158.

SLOAT, D.E.

1990. Growing up holy and wholly. Understanding and hope for adult children of evangelicals. Brentwood, Tennessee: Wolgemuth \& Hyatt Publishers Inc.

TRAHAN, M.

1995. A personal account: Bible-based group. In M.D. Langone (ed.), Recovery from cults. Help for victims of psychological and spiritual abuse (New York: W.W. Norton \& Company), pp. 140-147.

VANVONDEREN, J.

1989. Tired of trying to measure up. Minneapolis, Minnesota: Bethany House Publishers. 
Coetzer

Trefwoorde

Godsdienstige verslawing

Geestelike verslawing

Toksiese godsdiens

Toksiese geloof
Godsdiens: Middel tot verslawing of tot heling?

Keywords

Religious addiction

Spiritual addiction

Toxic religion

Toxic faith 